\title{
THE HISTORY OF MEDICINE IN THE AFRICAN COUNTRIES*
}

\author{
by
}

\section{H. J. O'D. BURKE-GAFFNEY}

A comprehensive survey of the history of medicine in some seventeen African countries would be monumental; and I propose to take as my theme a pattern which runs throughout the story, a pattern which seems to indicate that the short history of medicine in the Commonwealth countries in Africa-for in its significant aspects it spans little more than a century-is largely the history of their medical services; and it is the development of medicine through those services that I shall try to sketch very broadly and with, inevitably, many gaps.

Before the opening of Africa to exploration, settlement, trade and missionary enterprise, the African people were exposed to tremendous stresses and the mortality was immense. For medical treatment, they relied upon their indigenous practitioners, usually-although not always accurately-referred to as witch-doctors. These medicine-men practised largely by suggestion, incantations, charms and strange remedies; but with their knowledge of herbs and roots, they often discovered, perhaps by serendipity, a number of effective indigenous drugs. Some of these, indeed, have more recently been shown to have real therapeutic value and are known to be effective in conditions such as diarrhoea and some of the intestinal parasitic diseases. These discoveries were empiric: but then so were many of our own; and relative to cultural development, there is little basic difference between the application of their concoctions and the practice of carrying potatoes in the pocket as a cure for rheumatism. Nevertheless, their approach knew nothing of science: disease was held-as it is held in many primitive African communities today - to be the result of the direct activity of spirits, who had to be placated. Tribal mores were strong and the influence of the physical environment in the sense that we know it today was not considered.

The dawning of western medicine began gradually as exploration and settlement developed. Sporadic contributions had been made in the eighteenth century as a result of observations made by individual naval and military surgeons and missionary doctors, but these contributions were not appreciated fully at the time and their immediate influence was small.

However, some classic records remain. One of these was the account in 1803 by Thomas Winterbottom, Physician to the Colony of Sierra Leone from 1792 to 1796, of the Africans in Sierra Leone and 'the present state of medicine among them'. This is commonly claimed to contain the first English account of sleeping sickness. ${ }^{3}$ In fact, that account was given by John Atkins, a naval surgeon, who practised in

* A paper read at the Symposium on The History of Medicine in the Commonwealth, organized by the Faculty of the History of Medicine and Pharmacy, and held at the Royal College of Physicians of London on 23 September 1966. 


\section{H. J. O'D. Burke-Gaffney}

West African waters and who met the disease on the Guinea Coast in 1721.4 In his description of 'the sleepy Distemper in Negroes', in his book The Navy Surgeon [1734], he states: 'Their sleeps are sound, and sense and feeling very little: for pulling, drubbing, or whipping will scarce stir up sense or power enough to move, and the moment you cease beating, the smart is forgot'.

To these somewhat Draconian diagnostic measures were added a schedule of treatment which sounds a little drastic to our ears, but was no doubt not without benefit to the patient: 'bleeding in the jugular, quick purges, sternatories, vesicatories, acupuncture, seton, fontanels, and Sudden Plunges in the Sea: the latter is most effectual when the distemper is new, and the patient is not yet attended with a drivling at mouth or nose'.

Nevertheless, a sound basis had been established by more enlightened naval surgeons who were concerned not only with the maladies prevailing in warm climates but with those incident to getting there. The navigators venturing to Africa and elsewhere owed much to such far-sighted pioneers as Gilbert Blane and James Lind. ${ }^{1 \mathbf{a}, 2,3,4,21}$

A great deal of the early provision of medical facilities for Africans was owed to missionary enterprise. The example of David Livingstone contributed largely to the establishment of medical work as a recognized part of missionary activity. ${ }^{\circ}$ Others were soon to follow and medical missionary work rapidly expanded in West, East and South Africa through the efforts of various churches who increasingly provided training for their members and the establishment of hospitals, dispensaries and other medical facilities. ${ }^{12}$

For example, John Abercrombie in 1841 founded the Edinburgh Missionary Society for training medical students for missionary work. Yet in 1849 it was estimated that there were only 40 medical missionaries in the whole world. In 1863, lay doctors were associated with the Holy Ghost Fathers in Zanzibar; and the Universities' Mission to Central Africa and the Church Missionary Society started medical missionary services in various parts of Africa. The latter Society founded Livingstone College for instructing missionaries in the elements of practical medicine in 1893 and in 1897 founded a hospital in Uganda. The White Fathers had started work in the regions of the great lakes in East Africa in 1878 and in 1899 the White Sisters instituted health work there. 12

Within the British sphere of influence in Africa, it is not surprising that the first glimpses of activity should have been seen in the West African territories. Sierra Leone was among the oldest of these. When a free settlement of Negro slaves from Nova Scotia was begun there in 1787, through the vision of the philanthropist Granville Sharp, it was almost wiped out by disease at the very beginning. ${ }^{2}$ Although conditions apparently improved, through the use of ordinary basic methods of hygiene, the improvement benefited largely the settlers and their families alone. Health conditions throughout West Africa were bad; and yellow fever, malaria and other conditions took a toll so great that there was a constant struggle with disease, handicapped by a lack of knowledge. That remarkable woman Mary Kingsley in her West African Studies, published in $1899,{ }^{13}$ deplored prevailing apathy and noted that 'no trouble is taken to pull down the death-rate by Science'.

While expeditions and the various Chartered Companies had provided such medical 


\section{History of Medicine in the African Countries}

assistance as they could, it was sparse and not easy to come by. Indeed even two years after Sierra Leone had been handed over to the Crown in 1808, a Commission of Inquiry, referring to the medical department, stated: 'The provisions for this department, in a recent parliamentary vote, were a first and second surgeon, an apothecary and his assistants; and were these offices filled up in a suitable way they might have been sufficient to effect their purpose but such is the proportion of the salaries to the efficiency and ability required in the officers, that no competent person could be found to accept the first two posts'.

The early Administrations in Africa had at first mainly devoted the provision of medical services, through force of circumstances, to the needs of existing establishments. The wider extension of these to the African communities as a whole had to wait upon further knowledge, better communications, more staff and more money.

The 'insalubrity' of the climate blamed by the earlier observers as the source of illnesses in Tropical Africa was a misnomer: for the major enemy of progress was not the climate, but the mosquito; yellow fever, malaria, filariasis and diseases not then identified as arthropod-borne had dominated the scene and frustrated the efforts of pioneers to establish permanent health conditions. Malaria wrecked many expeditions and some of these are vividly described by Gelfand in his monograph Rivers of Death. ${ }^{10}$ With the first proof of the role of a blood-sucking insect as a vector of parasites pathogenic to man, Manson in 1879 had started a movement-for it was no less-which was to influence the future of tropical medicine and hygiene for all time. As one of his biographers, Alcock, ${ }^{1}$ wrote, Manson's discovery 'merely as a scientific achievement laid open a large new territory for investigation, started a flood of new ideas, and thus paved the way for fresh conquests over ignorance'. The encouragement and influence which Manson gave to Ronald Ross, culminating in his demonstration that mosquitoes were vectors of malaria parasites, is now familiar history: but although Ross's discoveries were first made in India, his further application of this knowledge to parasitic disease profoundly affected the health of all tropical countries and Africa was one of the first to gain. In 1899, Ross visited Sierra Leone and not only identified the vector of human malaria there, but subsequently set out proposals for dealing with it. In 1901 he prepared a report on the main measures required to reform health conditions in West Africa. Later he was to visit Lagos in Nigeria and Accra in the (then) Gold Coast and other investigations were to follow. ${ }^{2}$ In 1909 that great pioneer of tropical hygiene, Sir William Simpson, visited various parts of West Africa to study the existing organization of the medical services, particularly from the public health aspect. ${ }^{2}$ His very full report showed that while curative medicine had made considerable strides as a result of newer knowledge, prevention of disease-especially as regards the great mass of indigenous people-had made little progress: 'the conditions that have changed', he wrote, 'belong to the individual rather than to the locality'. ${ }^{2}$

The appearance of Mary Kingsley's book and Ross's investigations took place at about a period when a great step was taken in the organization of medical services in Africa and elsewhere. A far-sighted Colonial Secretary, Mr. Joseph Chamberlain, on the advice of Manson, addressed the General Medical Council and the principal British Medical Schools in 1888 with the proposal that medical officers appointed to 


\section{H. J. O'D. Burke-Gaffney}

tropical territories should have a special knowledge of tropical diseases. Ten years later in a despatch to all Governors of Colonies he advised that a special school for training in tropical medicine should be set up and that this subject should be taught on a wider scale in the principal medical schools in the United Kingdom. The London School of Tropical Medicine was founded in 1899: but it was not, in fact, the first, for a similar school had been established in Liverpool, earlier in the same year, not by government initiative but by the enthusiasm of a great captain of industry, $\mathrm{Mr}$. (later Sir) Robert Jones, whose interests in the West Coast of Africa were considerable.

The pattern of the present organization of medical services in Africa may be said to have taken shape in the establishment of an amalgamated West African Medical Service in 1902. Similar groupings were to follow: The East African Medical Services were amalgamated in 1903, though they separated later, but again achieved some closer union. The eventual logical step was the establishment of a Colonial Medical Service with appointments made in London, but with their own local administrations yet with a similar structure which varied according to their local requirements. In East Africa, for example, although the pattern of development followed lines similar to those in West Africa, there were a number of differing local factors which required special approaches. In East Africa generally there were eventually many Asian immigrants, and numerous European settlers in highland areas, and thus the racial distribution differed from that in West Africa. In Kenya, the medical department was first organized in 1905, when control of the country passed to the Colonial Office, although there had been a few medical officers in the days of the Chartered Company. In Uganda, there was a Government Hospital in Kampala in 1908, but Mulago Hospital, opened as a general hospital in 1922, was to become eventually the now magnificent teaching hospital for the medical school of the East African University College in Makerere. Uganda was indeed early in the field of training African medical personnel. From an initial course of training in Mengo in 1917, there developed in time the medical school with full facilities for professional training which now exists. The ravages of sleeping sickness which plagued Uganda in the opening years of this century was a particular factor in stimulating a new attitude in the provision of health services for Africans. In some infected areas, as many as 200,000 persons died. This resulted, among other awakenings, in a stimulus to the Royal Society to send commisions to study African sleeping sickness and one result of the heightened interest in this alarming disease was the foundation by the Colonial Office in 1908 of the Sleeping Sickness Bureau in London, formed to collect and distribute information on this disease. This organization was the forerunner of the Bureau of Hygiene and Tropical Diseases whose abstracting Bulletins are still a guiding light to current literature on tropical medicine and hygiene. The development of medicine and medical services in Tanganyika was a natural extension of the groundwork inherited from the former German East Africa. When the country became a Mandated Territory under British administration in 1923 medical services went ahead. The history of their development has been admirably related by Clyde. ${ }^{6}$ In Zanzibar, Nyasaland and the High Commission Territories of Basutoland, Bechuanaland and Swaziland, development took place slowly on the general pattern suited to their local conditions.

In South Africa, already with a long medical history, a Ministry of Public Health 


\section{History of Medicine in the African Countries}

was established in 1919. Here, development of medical services which had been occurring steadily for more than two hundred years, was naturally more sophisticated than that of its neighbours and it has progressed along western lines. The large factors of mining and of immigrant labour on a large scale from neighbouring countries posed, however, special problems of their own.

The medical problems of Southern Rhodesia were similar to those of the Union, though malaria was a greater problem. Northern Rhodesia (now Zambia) has had problems of sleeping sickness and the additional health questions posed by the large amount of labour in its copper mines. In 1948, Southern Rhodesia acquired a Minister of Health and the Medical Department was subdivided into curative and preventive services.

While Egypt and the Sudan no longer fall within the scope of this survey, their past contributions to the development of medicine in African countries of the Commonwealth have been considerable. A great deal of intensive work on tropical diseases, especially on schistosomiasis, has been carried out in these countries, much of it by Commonwealth workers in two world wars; and the contributions made by the Wellcome Tropical Research Laboratories in Khartoum, equipped by Henry Wellcome in 1902, and the training of Sudanese in the Kitchener School of Medicine founded in 1924 have been significant landmarks. The pioneer work of such great figures as Balfour and Chalmers is well known. ${ }^{22}$

It would not be practicable within the compass of a single lecture-and it would in any case, be extremely boring to the listener-to list the detailed forms which medical developments took in the different countries. Basically, the ground structure was the same; a central administration, medical staff deployed on regional and district bases, with hospitals of varying grades, health centres, dispensaries and ancillary staff according to the needs and the resources of particular areas. In addition, there are general and specialized laboratories, and, in larger centres, research institutes, sleeping sickness organizations where these are required, mass campaigns against endemic diseases and-as in Nigeria-mobile units derived from these and now used as 'shock troops' for dealing with epidemics, surveillance and other activities. ${ }^{19}$ Today in the independent countries, the pattern tends to be that of Ministries of Health, rather than of the former Medical Departments.

Most important are the training centres, which vary from full-scale medical schools, such as those in Ibadan in Nigeria, Makerere in Uganda, and the University of Rhodesia, to others training more specifically various grades of medical auxiliariesmedical assistants with a broad training not up to graduate status, laboratory technicians, field assistants and various dispensers and 'Aides', all with a degree of knowledge sufficient to deal with the kind of problems which might be encountered at their level in the field. The emphasis on training today is on prevention and many campaigns are frequently sponsored by W.H.O., after which not only are the local staff encouraged to maintain the work themselves, but where possible the machinery is integrated into the general public health services.

It must not be thought, however, that medicine in Africa has developed solely from the efforts of the territorial administrations. Reference has already been made to the great work carried out by the medical missions. In addition, the increase in 


\section{H. J. O'D. Burke-Gaffney}

the industrial, agricultural, commercial, mining and other forms of development brought with it many companies and other agencies. Several of these have their own medical staffs, some of them highly organized. Not only, therefore, is occupational hygiene finding its place in the new Africa, but these agencies have much to contribute to health in general both alone and in association with governmental enterprise.

To discuss the prevailing diseases of the African countries in the Commonwealth would be a story in itself. In any case most of the diseases commonly called tropical are present there as elsewhere, and perhaps the only truly indigenous one is African trypanosomiasis. It would not perhaps be out of place, however, to note that as the means of controlling these diseases improve and are extended, they will bring more into perspective the importance of the cosmopolitan diseases. These have always been there, less obtrusive perhaps because of the more specifically tropical conditions, but likely to be more so as the pattern of living changes. Cerebrospinal meningitis has been constantly present and has caused many serious epidemics, especially in West Africa, during the century. ${ }^{20}$ Measles is a prominent killing disease of African children. Tuberculosis is a major problem and despite modern advances in treatment and prevention these measures are commonly restricted or modified by logistics and cost, though some notable advances have been made. ${ }^{8}$ Venereal disease is widespread. Occupational disease is likely to become more prominent as development advances. The wide studies and knowledge of virus diseases have served to uncover many infections which were hitherto unidentified. For example, it is only in recent decades that the extent of poliomyelitis in Africa has been recognized. Of special interest is the recognition of increasing numbers of infections caused by arboviruses, some indeed having been identified originally in Africa. Two of these are of special interest. Chikungunya virus was first isolated as a result of a study of a dengue-like outbreak in Tanganyika in 1952.14,17,18 Now it is a well recognized member of the arbovirus group and its incidence has been shown far afield, as in its association with haemorrhagic and dengue-like fevers in such countries as India and Thailand. O'Nyong-Nyong fever, also a dengue-like disease, was identified in Uganda in 1959.11 Of particular interest was a finding that it showed some interference with outbreaks of malaria? and this phenomenon is being pursued.

A very topical subject, with an African history, is Burkitt's tumour, a lymphoma notably found in African children. It was given prominence by Burkitt ${ }^{5}$ in Uganda in the 1960s but has since been detected widely in many other countries, in various subjects and forms. Epidemiological studies showed a striking association between topographical, meteorological and other features and conditions favourable to mosquito breeding. This suggested a possible arborvirus aetiology and vigorous studies are being pursued, not only in Africa, but in many virus research institutes in Europe and the United States, on this aspect of the subject. The implications of these studies in the investigation of a possible role of viruses in the aetiology of cancer are enormous; and although a number of viruses have been isolated from Burkitt's tumours, none in fact has so far been incriminated as being causative.

What were the factors which influenced the course of medicine in Africa from the first gropings of the mid-nineteenth century to the vast developments in the twentieth? There were a number, at first sight unrelated, but to some degree overlapping and they 


\section{History of Medicine in the African Countries}

weave between them an enlightening story of medico-social evolution. The central point of all this was the African himself, with his soil, his animals, his tribal mores, a whole environment which was engaged in a constant struggle with two formidable foes-poverty and parasites.

Basically, there were certain operating factors. There was the more enlightened attitude of the Colonial Administrations. There was the co-operation of missionary, governmental and non-governmental agencies in the joint application of knowledge and resources. There was the opening up of trade, industry, commerce and communications and with it the provision of men, money and momentum to apply practical measures. There was a vast and rapid increase in scientific knowledge and research with the discovery of new drugs, antibiotics, insecticides and the application of public health engineering. There was the development of W.H.O. with its help and guidance. There was the effect of wars, especially two world wars, which influenced the application of practical medical measures, both for better and for worse. There was the impact of migration and urbanization, with all the consequent results of the breaking of tribal and family ties and the exposure to tuberculosis, venereal and other diseases of overcrowding. There was the achievement one by one, of national independence by African countries and of a new status and pattern of living. Above all there were two outstanding factors, the recognition of the over-riding importance of preventive rather than solely curative medicine and the education, particularly the health education, of the peoples themselves.

The South African war had produced a striking object lesson in the need for preventive medicine in the field. For some 7,000 men killed in action, for example, there were 57,000 affected by typhoid. ${ }^{2}$ The First World War broke out with a knowledge of tropical medicine already established on a sound basis: but there was still much to learn and a great stimulus was provided by the urgent necessity for protecting troops against disease in the field; and tropical medicine emerged enriched by its experience and triumphant in a newer knowledge which was soon applied to the problems of peace. The Second World War found the African countries better equipped for the formidable tasks which faced them; and while the civil medical departments were greatly depleted, they were constantly learning the new lessons which the various campaigns in different regions of Africa and elsewhere had taught them. The introduction of many synthetic antimalarials, drugs for use against sleeping sickness, schistosomiasis and other helminthic diseases and the use of sulphones for leprosy played a notable part. The development of D.D.T. and related insecticides, and later of organophosphorus and other types of insecticides, provided new weapons against the vectors of disease. Improved molluscicides strengthened the control of schistosomiasis. The development of a safe and effective yellow fever vaccine has had so striking an effect that yellow fever-once the scourge of Africa-is now a comparative rarity there. Antibiotics, curative in so many diseases, reduced the incidence of yaws to a manageable proportion in many areas.

But these 'wonder drugs' and pesticides were soon to show their limitations. Resistance of parasites and vectors developed in a number of areas, but fortunately many of these drugs and pesticides were replaced by newer discoveries. The application of the newer measures was, furthermore, beset by formidable difficulties, logistic, 


\section{H. J. O'D. Burke-Gaffney}

sociological and financial, so that the general eradication of insect-borne disease in rural areas of Africa is not yet in sight.

Meanwhile, the human element, as one might expect, dominated much of the scene. Industrialization and urbanization, already referred to, played an increasing part. The rapid development of the great mining areas in Kimberley and the Rand had brought workers from many parts of Africa. Other developments in West and East Africa brought their own problems. The copper mines in Zambia needed measures to combat occupational disease. Fortunately, where mining activities were adequately controlled, such organizations as the Silicosis Bureau and the arrangements for regular examination of labourers dealt adequately with such occupational diseases and their consequences and they have been reduced to appreciably low proportions.

Soon after World War II the drive for independence in the African countries took on a new momentum. When these countries achieved their independence one by one, they were left with a great legacy of highly efficient medical and public health organization, built on the western pattern and with the machinery ready to take over. But machinery is not enough: once again the human element is paramount. All those in the medical services, expatriate and indigenous, had been largely trained in the ways of western medicine: but few had been trained to the quite specific needs of medicine in Africa, their priorities and the best ways in which to apply them. It became apparent -and much recent writing has supported this-that much training for medicine in Africa should be carried out in Africa and that until education is much more widespread the number of conventionally trained doctors cannot hope to deal singlehanded with the vast health problems of rural Africa. The standards of medical qualification must not be reduced: but the emphasis needs to be put on the specific problems to be faced in rural Africa. Much groundwork remains to be done in health education, by 'selling' to the people the needs for health and above all to show them how to apply the basic measures themselves. Much of this can best be done in the field through the influence of Africans themselves, who can translate the concepts of modern science in terms which their people can understand; and this should be encouraged throughout the social scale from the Medical Officer of Health to the Village Headman. Fortunately, in many countries facilities for training are being developed in increasing numbers. Meanwhile, the goal must be the eventual application of full scientific measures, the increasing education of fully qualified doctors, adapted where necessary to local needs, but with the use of every discipline which modern science has to offer: and this implies not just medical science but sociology, psychology and all those approaches necessary to meet in a humanitarian way the cultural needs of the people concerned. The first priority is not for expensive equipment: it is for enlightened doctors.

Fortunately research is not lacking and indeed in many parts of Africa it has reached a high state of maturity. One can but look, for example, at such agencies originally formed, as the East and West African Councils for Medical Research, the East African Medical Survey, the East African Tsetse and Trypanosomiasis Research and Reclamation Organization, the Viral Research Institutes in Entebbe and Lagos, the West African Institute for Trypanosomiasis Research and numerous other institutions, committees and research laboratories either former or existing. 


\section{History of Medicine in the African Countries}

Many pilot schemes on the control of diseases in various parts of Africa have pointed the way to wider measures.

The many developments in medicine in Africa have achieved some remarkable results and indeed some of the projects undertaken are themselves classics in the history of tropical health. A few examples may give some indication of the compass of some of these undertakings.

One was the introduction of sleeping sickness settlements in East Africa associated so closely with the name of George MacLean, though it eventually involved a tremendous combined operation of many disciplines and agencies. ${ }^{24}$ The basic concept was that in bush country infested with tsetse flies in Tanganyika where Trypanosoma rhodesiense infection occurred there were some natural clearings unattractive to the fly and with relatively small populations. The purpose of the scheme was to enlarge those areas and to transfer to those new clearings people from villages in bush areas which were infested with tsetse flies. This meant a complete change of their way of life and the development of a new environment which would embrace all the necessities for the growth of self-supporting communities. This was resettlement on a vast scale, with provision of water supplies, dwellings, farm animals and the development of crops. Whole communities were thus separated from tsetse flies and hence from infection with sleeping sickness. A similar system was also applied in country of a different kind such as that adjacent to rivers and lakes where $T$. gambiense was the parasite, and various methods of approach were carried out in other parts of East and West Africa.

In West Africa a system of selective clearing was introduced, and it was in Nigeria that a classical undertaking was made in resettlement and formation of thriving communities in an area heavily infected with $T$. gambiense sleeping sickness. This was in the Anchau area where a scheme was undertaken to control the vector flies in a corridor of some $70 \times 10$ miles. $^{16}$ This ultimately resulted in the disappearance of trypanosomiasis in man and animals and the people themselves maintained the area which they had cleared.

Both of these enterprises called for closely planned and executed operations not only by the medical department, but by administrative, veterinary and agricultural departments. This underlines what cannot be repeated too often regarding public health advances in Africa, namely that it is not just a departmental problem, but one which involves close consultation and activity between all the agencies and disciplines which contribute to the full development of the African in his environment.

Brief reference may be made to two other projects which illustrate the need to foresee the implications for community health in the undertaking of large-scale industrial schemes in Africa and the hazards of man-made obstacles to health. The Volta River hydro-electric scheme in Ghana posed many problems, not the least of which was the settlement and protection of people from disease resulting from flood. Measures had to be taken to deal with such conditions as malaria, ankylostomiasis, and schistosomiasis, and this involved careful planning and execution by the health authorities. ${ }^{15}$ The construction of the Kariba Dam in the Zambesi Valley raised comparable problems and a comprehensive medical organization was developed to deal with them. ${ }^{23}$ Detailed accounts of these approaches have been written and would repay reading. 


\section{H. J. O'D. Burke-Gaffney}

It is clear from the foregoing that clinical medicine, while it must always have its proper compassionate place in relieving individual suffering in Africa, should develop hand in hand with increasing preventive efforts. It is curious that in western countries the greatest advances in therapeutics have occurred in the last half century, while preventive medicine was already taking shape in the Victorian era. In tropical Africa the position was, in a sense, reversed. The first gropings after the control of tropical diseases were based on the use of such drugs and empiric treatments as were available, but the concept of prevention had to await the newer knowledge of transmission of disease and of its control. It is true that the prophylactic use of some of the newer drugs may be the only means, by reason of limited communications, men and money, for mass prevention of a number of diseases in rural areas of Africa. But in others wider preventive measures, whether against diseases, vectors or ignorance, are the means in which increasing hope must be placed in the future.

In the development of medicine in Africa from scientific ignorance to organized community health the groundwork is sound and the pattern clear and flexible enough to be adapted to various local needs: yet it must be repeated that however wellorganized the practical measures, the future must depend on increasing education of the people themselves. The problems are basically African problems and their solutions must ultimately rest with trained Africans at increasing levels of general, health and medical education. For some time to come many developing countries will need expert outside help and guidance in solving their medical problems. Such is already available through links with some British universities and other institutions who second staff to the needy countries, and by fellowships and other forms of aid enabling experts to spend periods in some of the former British African Territories to help in ad hoc projects or in an advisory capacity. In time, the Africans will take over completely themselves; but whatever form their medical facilities may take, the objectives will be the same-to pursue the war on what President Nyerere of Tanzania succinctly described as "poverty, ignorance and disease'6 so that the peoples of Africa may be capable of leading full and healthy lives, free from the hazards which decimated their forefathers and many of those, too, who went to Africa to help them. To this objective Commonwealth Medicine has been proud to contribute in the past and is proud to continue to contribute in the interim in that tradition so well summarized in the motto of the Royal Society of Tropical Medicine and HygieneZonae torridae tutamen.

\section{REFERENCES}

1. Alcock, A., Trans. R. Soc. trop. Med. Hyg., 1922, $14,1$.

1a. Balfour, A., Trans. R. Soc. trop. Med. Hyg., 1925, 19, 189.

2. Balfour, A., and Scotr, H. H., Health Problems of the Empire, London, W. Collins, 1924.

3. Brown, J. R., Med. Servs J. Can., 1965, 21, 645.

4. BURKe-GAFFNEY, H. J. O'D., E. Afr. med. J., 1933, $10,100$.

5. BuRKITT, D., Nature, Lond., 1962, 194, 232.

6. ClYDE, D. F., History of the Medical Services of Tanganyika, Dar-es-Salaam, Government Press, 1962.

7. De ZuluetA, et al., Bull. Wld Hith Org., 1962, 26, 135.

8. Fox, W., Brit. med. J., 1964, i, 135. 


\section{History of Medicine in the African Countries}

9. Gelfand, M., Cent. Afr. J. Med., 1965, 11, 192.

10. Idem., 'Rivers of death', Cent. Afr. J. Med., supplement, August 1965.

11. HadDow, A. J., et al., Trans. R. Soc. trop. Med. Hyg., 1960, 54, 517.

12. HAILEY, RT. HON. LORD, An African Survey, London, Oxford University Press, 1957.

13. KIngsley, MARY, West African Studies, London, 1899.

14. Lumsden, W. R. H., Trans. R. Soc. trop. Med. Hyg., 1955, 49, 33.

15. MacDonald, G., Ibid., 13.

16. NASH, T. A. M., The Anchau Rural Development and Settlement Scheme, London, His Majesty's Stationery Office, 1948.

17. Robinson, M. C., Trans. R. Soc. trop. Med. Hyg., 1955, 49, 28.

18. Ross, R. W., J. Hyg., 1956, 54, 172.

19. Scotr, D., Ghana med. J., 1962, 1, 19.

20. Idem., Epidemic Diseases in Ghana, 1901-1960, London, Oxford University Press, 1965.

21. Scotr, H. H., A History of Tropical Medicine, London, Edward Arnold, 1939.

22. SQUIRE, H. C., The Sudan Medical Service, London, Heinemann, 1939.

23. Webster, M. H., Cent. Afr. J. Med., 6, supplement, October 1960.

24. Wricocks, C., Aspects of Medical Investigation in Africa (University of London Heath Clark Lectures 1960), London, Oxford University Press, 1962. 